\title{
MRC1 Gene
}

National Cancer Institute

\section{Source}

National Cancer Institute. MRC1 Gene. NCI Thesaurus. Code C104633.

This gene is involved in endocytosis of glycoproteins by macrophages. 